\title{
Hoax amidst The Covid-19 Pandemic
}

\author{
B. Setiawan ${ }^{1}$, P. Pawito ${ }^{2}$, S. Hastjarjo ${ }^{3}$ \\ ${ }^{12,3}$ Department of Communication Science, Universitas Sebelas Maret Surakarta, Indonesia \\ ${ }^{1}$ bennisetiawan@student.uns.ac.id, ${ }^{2}$ pawito_palimin@staff.uns.ac.id, ${ }^{3}$ sri.hastjarjo@staff.uns.ac.id
}

\begin{abstract}
This paper aims to contribute and provide insight to the community related to the hoax phenomenon in the midst of a pandemic. Hoax needs to be prevented so that people get the right information and perform appropriate behavior amid the Covid-19 pandemic. This article employs a qualitative analytic approach by taking examples of the hoax on social media. The results of this study indicate that social media is a means of spreading hoax therefore being wise in utilizing media is required. Wise, ethical, critical reasoning and tabayun (clarifying) are the main attitudes to free from hoax problems. Preventing the growing hoax in the middle of a pandemic is required to save humanity.
\end{abstract}

Keywords: Social Media, Covid-19 Pandemic, Critical Reasoning, Media Ethics

\section{Introduction}

Fake news (hoax) continues to overwhelm the lives of the Indonesian people. The community seems unable to restrain the increasingly massive exposure of the hoax. The Ministry of Communication and Information Technology notes that in the last three years, there was an average of 800 thousand hoax contents. This number is equivalent to 2,250 per day. In other words, there are 93 contents containing fake news every hour, or more than one content every minute [1].

Hoaks seem to find a new place to plunge humans in the middle of the Covid-19 pandemic. The Ministry of Communication and Information noted that until mid-April 2020, there were 554 hoax issues that spread amid the Coronavirus pandemic (Covid-19). The hoax is spread across 1209 digital platforms, such as Facebook, Instagram, Twitter, and YouTube. There are currently 89 suspects related to the Covid-19 hoax cases. Of the 89 suspects, 14 have been arrested [2].

Some hoaks look like a fact as they have spread through chain messages via the WhatsApp group, for instance news on Gargling with warm water added with salt or vinegar can remove Coronavirus. The news spread rapidly in the community on March and re-emerged on May 2020.

The explanation of the hoax buster at the covid-19.go.id [3] webpage states that the news did not only spread in Indonesia. Similar information also appeared in various parts of the world. However, after further investigation, the claims about salt and warm water which can get rid of the coronavirus is inaccurate. The World Health Organization (WHO) said that it's just a myth.

In Medio Mei, a hoax appeared about the "Bajaj Bajuri" sitcom which predicted the Covid19 pandemic 17 years ago. "Believe it or not, COVID-19 was predicted by the Bajaj Bajuri sitcom 17 years ago," wrote the owner of the Facebook account Saifudin Ali yesterday (5/14). 
On YouTube, various channels upload similar video footage with various arbitrary narratives. One of them is the NANGKE CHANEL canal. "One of the Bajaj Bajuri shows predicted the Covid-19 many years ago," wrote the channel in the description column.

When the news is traced, the scenes in the Bajaj Bajuri series that are perceived to show the Covid-19 are episodes of "Katakan saja ogah berpuasa" (Say you are unwilling to do fasting). Jawa Pos found the full version of the episode uploaded by the Bang Ros channel on April 28, 2020. In fact, the Bajaj Bajuri video footage that circulated the past few days presented the situation when SARS hit the world rather than Covid-19 [4].

A similar case also occurs, which is associated with the Bimbo singer group. Bimbo song titled Corona which was just released spread and is considered to have appeared since 30 years ago. The narration uploaded by Twitter users is as follows: "A Corona song produced by Bimbo which was considered ordinary 30 years ago ... today it is proven to be extraordinary ...SUBHANNALLAH ..," wrote @ cahndlodhog. The corona song composed by bimbo which 30 years ago was perceived ordinary... today it is proven...extraordinary... SUBHANNALLAH.. pic.twitter.com/ulo6FL24DL - cah ndhlodhog 911 (@cahndhlodhog) April 10, 2020. According to the Acil Bimbo, the song was just recorded in March 2020 [5]. The Corona song was created by Bimbo indeed, but it was not 30 years ago.

The question that arises then is how to unravel hoax in the current pandemic era? This paper aims to contribute and offer insight to the community related to the hoax phenomenon in the midst of a pandemic.

\section{Method}

This study utilizes an interpretive qualitative approach. The interpretive qualitative approach describes a narrative in detail. This study views a fact as an interesting entity in understanding social meaning. Facts are specific and contextual actions that rely on the interpretation of some people within the social sphere [6]. This study gathers hoax data from social media. The hoax is collected based on the publication categories, then they are interpreted based on the meaning understood by the community.

\section{Results and Discussion}

A large number of hoax suggests that Indonesia is an emergency state of hoax. Imagine, if one person can produce and share hundreds of thousand hoaxes and if there are 20 people doing the same thing, there will be millions of hoaxes produced.

The mass-produced and viral-spread hoax will fill public space. The public sphere borrowing the term of Habermas [7]- will be far from civilization. Even though public space is a medium to build networks and cooperation towards the main community.

When public spaces are filled with the hoax, humans have directly collided. Humans are confronted with the reality that may lead them in the wrong choices namely, blaming others based on unreliable news. When someone's anger and emotion have been provoked, violence will be the next choice. Violence triggered by the hoax will bring banality.

The banality of violence, borrowing the term of Arendt [8], which is covered with fake information is a bad period of the state of society. The public will struggle over their lack 
of understanding in comprehending the information. The community eventually becomes victims. Victims of a hoax ferocity that can trigger division, hostility, and war [9]

Furthermore, hoaks are heresy. Hoaks will poison people's thinking. When people are exposed to hoaks, they will find difficulty to distinguish between right (haq) and wrong (bathil).

Hoax will also encourage community divisions because the hoax will provoke public awareness. When provocation continues to overwhelm consciousness, one will possibly perform anarchist actions due to wrong understanding.

When hoax flood the people's information systems, it will be difficult for them to think clearly. People can be mired in a wrong understanding because right is perceived wrong and vice versa. This is an episode of breaking critical reasoning where reasoning is difficult to distinguish between right and wrong. In this situation, reasoning finds difficulty to insert the truth into human behavior. Also, it easy to do bad things for the sake of personal and group interests [10].

For sure, we cannot surrender to any form of hoax. Law Number 11 of 2008 regarding Information and Electronic Transactions [11] strictly rejects the existence of hoax. Article 28 (1) states that every person intentionally and without the right to spread inaccurate and misleading news resulting in consumer losses in electronic transactions, (2) every person intentionally and without the right to spread information intended to incite hatred or hostility of certain individuals and/or groups of people based on ethnicity, religion, race, and intergroup.

The penalty for violating this article is regulated in Law Number 19 of 2016 concerning Amendment to Law Number 11 of 2008 on Information and Electronic Transactions stipulated in Article 45 (A). Article 45 A (1), every person who intentionally and without the right to spread invalid and misleading news that results in consumer losses in electronic transactions referred to in article 28 paragraph (1) shall be sentenced to a maximum imprisonment of 6 (six) years and/or a maximum fine of Rp 1,000,000,000 (one billion rupiahs). (2) Every person who intentionally and without the right to disseminate information intended to incite hatred or hostility of certain individuals and/or groups of people based on ethnicity, religion, race, and intergroup as referred to in article 28 paragraph (2) will be sentenced to a maximum imprisonment of 6 (six) years and/or a

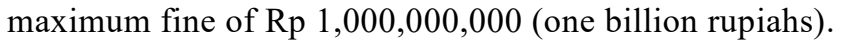

Hoaxes have been proven to be misleading and the law has set a ban on a hoax, but why does it still happen and tends to increase amid the Covid-19 pandemic?

A joint effort against the spread of hoax is required. One important pillar is mass media. President of Joko Widodo has called for mass media to unite against the spread of hoax. The call encourages the media to realize quality and integrity journalism.

Mass media, especially print media, are now quite selective in taking news from social media such as Twitter and Instagram. The retrieval of news from social media often creates misunderstandings for readers. This misinterpretation will lead to the hoax. The printed mass media continues to be committed so that the public will be more critical of the news presented.

However, this effort is confronted with obstacles. The influx of social media that is faster than the daily print news encourages people to get instant information. People are often confused and are not critical to the information that circulates. Therefore, a misleading network of hoax emerges.

In fact, most hoax decreases quality reasoning as a hoax is produced by a group of trained and skilled people in using media. They gather and build a network to spread fake news for 
personal and group interests. When they are getting tough and continue to produce hoax, they may break the nationality.

This condition illustrates how the community still exists within the naive confinement of awareness - borrowing strata of consciousness of Paulo Freire. The public is still unable to distinguish true and false news. They will grasp any information without critically comprehending the information.

Critical awareness can be developed by reinforcing good and correct reading habits. Reading newspapers, books, and scientific works can guide a person to gain objective awareness. This is because written books are produced based on contemplation. Reading books and scientific works are silent works that require perseverance.

Critical reasoning can be reinforced by the sharpening and 'encouragement' of good reading habits. The habit will ignite the subconscious to understand the logic of information. Through the sharpened awareness, one will easily distinguish the fake and right news. Is the news worth sharing with others? When the news becomes viral, will it encourage a civilization work or not?

The habit of sharing news without confirming its contents is misconduct. This habit is usually performed by those who are 'lazy' to read. They prefer to 'share' information even though they don't understand its contents.

Therefore, the hoax that threatens the existence of a civilized order needs to be confronted with a critical attitude that can be developed by improving reading awareness. The hoax will decrease when someone doesn't spread the unconfirmed news.

He chooses and sorts out which news is 'useful' and needs to be shared with others. He will also stop spreading news that is 'unuseful' for the benefit of the community. The benefit can only be obtained when someone succeeds in clarifying (tabayun) [12] the information he obtained.

Tabayun (clarifying) is very important in this rapid information exchange era. When we are reluctant to do so, we will get a liar stigma from others. This is one of the dangers of a hoax. In this case, someone who likes to spread information without confirming will be judged as a 'liar', an image that we certainly don't desire to have. Good and quality reading awareness will save us from the negative perception of others. We will also be saved from hoax that often misleads ourselves and others.

One way is to improve the quantity and quality of our reading. Reading a lot of books or authoritative references may help someone reduce the potential dangers of hoax.

Reading is not only part of our obedience in carrying out God's commands (Iqra) [13], but also it is beneficial to improve the quality of our nationality. Hoax can only be countered with critical awareness realized by fostering good reading habits. These habits need to be improved from the education dialogue space [14].

In addition, people need to get a digital literacy education. One of them is by encouraging the public to read and spread the news from the press that has been verified by the Press Council. The Press Council noted that there were at least 43,000 online media.

Of that total, there are only 40 verified online media. This is less than one percent of the total online media that exists. The great number of unverified media greatly contributes to the high rate of the hoax as they do not hold rules of journalism. This large number of unverified online media also lead to fake press.

With regard to this, digital literacy is important for the community. Society requires digital literacy. When people have good digital literacy, they will not be easily persuaded by the hoax. They will be critical of the information they receive. When people already have an 
imune to restrain hoaks, false and fake news will not affect them. Hoax will disappear when the community has never accessed and/or shared fake news with others.

Digital literacy needs to be enhanced by media ethics. This is because the aim of literacy is to increase the user's capacity in utilizing social media critically and ethics will guide users to be reflective when communicating. Ethics serve to direct the communication actors to make sure whether the communication has been performed in accordance with the norm and provided benefits or not [15].

Sounding and practicing social media ethics today is a necessity since without ethics social media will only become a rubbish heap of civilization. One of the important ethics in preventing the spread of hoax is to understand and clarify the contents of information. After understanding, one is to be wise in order not to spread (share) the fake information to others. Simply performing this habit is a good practice of social media ethics today. We certainly do not desire to add a problem for our nationalities today. Improving our awareness through ethics by holding to spread false news becomes an important lesson in media literacy.

Let us embed a slogan when interacting on the internet, "Think Before You Act" and "Turn Back Hoax" [16]. By doing so, hoax can be decreased and its dangers can be prevented.

Prevention of hoax that is widely spread through social media of WA amidst the pandemic will change people's behavior. As suggests in cultivation theory, when someone is exposed to the media continuously, they will perceive that reality is like what is displayed in the media (in this case is social media).

The spread of fake news, for example in the case of drinking warm water added with vinegar which can cure Covid-19, may mislead people and create new diseases. Tasnim, Hossain, \& Mazumder [17] state that the spread of fake news about people's attitudes toward Covid-19 has blurred the supposed healthy behavior and promoted wrong practices. The decrease in healthy behavior and the overwhelming wrong practices can increase the spread of the virus and ultimately cause poor physical and mental health effects for individuals.

Hoax in the middle of the pandemic apparently leads to new diseases. The new disease will increasingly worsen the problem and anxiety of the community. Covid-19 pandemic will also be difficult to unravel as the public has been exposed to much fake information. The great exposure to misleading information also creates a problem, namely the emergence of new habits and diseases in the community.

The note of the World Economic Forum shows that fake news is one of the threats in today's society because this information may spread quickly and is often inaccurate and misleading. In addition, fake news is widely shared compared to evidence-based news among social media users and therefore this has a potential to influence individual decision making. The researrch shows that there is more fake news published and shared on Twitter [18].

The spread of fake news on Twitter, like Corona-related songs is proof that social media can not restrain from the hoax. In fact, social media encourages the spread of hoax.

Ironically, what is experienced by social media platforms also occurs online media. Online media prefers to publish news with appealing titles, although the truth of the news is still questionable. The findings of Pennycook, McPhetres, Zhang, \& Rand [19] state that people simply believe in attractive titles. They fail to critically think about their accuracy. They then immediately share the news with others and assume that the information is true.

In this regard, a journalist plays a vital role in the process of building awareness. Journalists need to present the news in detail and ensure that the news they write should be reliable, not just attracting the viewers. The dramatic increase of hoax in the middle of a pandemic is expected to remind the journalists, especially online media journalists to be aware and eliminate fake news sources. A journalist for Lowe [20] needs to be called upon to return 
to his important role in educating the community. Online media journalists need to be aware that viewers are not everything. The most important thing for a journalist is to ensure that the news he produces is accurate and verified. This is the important role of an online media journalist in preventing hoax in the middle of a pandemic.

\section{Conclusions}

Finally, being wise in utilizing media is the key to cope with hoax. Social media is like a vast wilderness that requires us to sort out and choose which wood is beneficial for us. If we just cut down the trees arbitrarily, a new disaster will occur. Likewise, if we want to exist and become the first disseminator of information while the information is inaccurate, it will be a disaster for others. Wise, ethics, critical reasoning, and tabayun become our main assets to be free from the hoax. Preventing the growing hoax in the middle of a pandemic is badly needed to save humanity.

\section{References}

[1] B. Setiawan, "Indonesia darurat hoaks?. Informasi, vol. 48. no. 2, pp. v-vi. 2018a.

[2] Detikcom. (2020). Menkominfo: Ada 554 Isu Hoax soal COVID-19, 89 Orang Jadi Tersangka https://news.detik.com/berita/d-4982087/menkominfo-ada-554-isu-hoax-soal-covid-19-89-orangjadi-tersangka, accessed on June 23, 2020.

[3] Covid19.go.id (2020). [SALAH] Campuran Garam dan Air Hangat Mampu Hilangkan Virus Corona https://covid19.go.id/p/hoax-buster/salah-campuran-garam-dan-air-hangat-mampuhilangkan-virus-corona, accessed on June 23, 2020.

[4] Jawa Pos, (2020). Hoax Bajaj Bajuri ramalkan Covid-19, https://www.jawapos.com/hoax-ataubukan/16/05/2020/hoax-bajaj-bajuri-ramalkan-covid-19/, accessed on June 23, 2020.

[5] Kompascom, (2020). "[KLARIFIKASI] Lagu Corona Karya Bimbo Disebut Sudah Ada Sejak 30 Tahun Lalu", https://www.kompas.com/tren/read/2020/04/11/171300265/-klarifikasi-lagucorona-karya-bimbo-disebut-sudah-ada-sejak-30-tahun-lalu?page=all, akses 23 Juni 2020.

[6] J. Rahmat, Metode Penelitian Komunikasi. Bandung: PT Remaja Rosdakarya. 2005.

[7] J. Habermas, "The public sphere: an encyclopedia article (1964)". The idea of the public sphere: A reader, 114-120. 2010.

[8] H. Arendt, On violence. New York: Harcourt, Brace \& World. 1970.

[9] B. Setiawan, "Melawan hoaks". Investor Daily, Wednesday, 28 March 2018b.

[10] B. Setiawan, "Menyoal hoaks membangun". Investor Daily, Saturday, 27 January 2018c.

[11] Undang-Undang Nomor 11 Tahun 2008 tentang Informasi dan Transaksi Elektronik (Law Number 11 of 2008 regarding Information and Electronic Transactions).

[12] Q.S. al-Hujurat, (49:6).

[13] Q. S. al-Alaq, (87: 1).

[14] B. Setiawan, "Hoaks, kesadaran kritis, dan kebangsaan". Media Indonesia, Monday, 23 April 2018d.

[15] P. Rianto, "Literasi digital dan etika media sosial di era post-truth". Interaksi: Jurnal Ilmu Komunikasi, vol. 8, no. 2, pp. 24-35. 2019.

[16] Y. D. Astuti, "Peperangan generasi digital natives melawan digital hoax melalui kompetisi kreatif". Informasi, vol. 47, no. 2, pp. 229-242. 2017.

[17] S. Tasnim, M. M. Hossain, \& H. Mazumder, "Impact of rumors and misinformation on COVID19 in social media. Journal of Preventive Medicine and Public Health, vol. 53, no. 3, pp. 171174. 2020. 
[18] C. P. Rodríguez, B. V. Carballido, G. Redondo-Sama, M. Guo, M. Ramis, \& R. Flecha, "False news around COVID-19 circulated less on Sina Weibo than on Twitter. How to overcome false information?. International and Multidisciplinary Journal of Social Sciences, vol. 9, no. 2, pp.1-22. 2020.

[19] G. Pennycook, J. McPhetres, Y. Zhang, J. G. Lu, \& D. G. Rand, "Fighting COVID-19 misinformation on social media: Experimental evidence for a scalable accuracy-nudge intervention. Psychological science, vol. 31, no. 7, pp. 770-780. 2020.

[20] H. Lowe, "An online hoax reminds journalists to do their duty". Journal of Mass Media Ethics, vol. 27, no. 1, pp. 62-64. 2012. 